This item was submitted to Loughborough's Research Repository by the author.

Items in Figshare are protected by copyright, with all rights reserved, unless otherwise indicated.

\title{
Capturing volunteered information for inclusive service design: potential benefits and challenges
}

PLEASE CITE THE PUBLISHED VERSION

http://dx.doi.org/10.2752/175630613X13584367984947

PUBLISHER

(c) Bloomsbury Journals (formerly Berg Journals)

\section{VERSION}

AM (Accepted Manuscript)

LICENCE

CC BY-NC-ND 4.0

\section{REPOSITORY RECORD}

Parker, Christopher J., Andrew May, and Val Mitchell. 2019. "Capturing Volunteered Information for Inclusive Service Design: Potential Benefits and Challenges”. figshare. https://hdl.handle.net/2134/11589. 
This item was submitted to Loughborough's Institutional Repository (https://dspace.lboro.ac.uk/) by the author and is made available under the following Creative Commons Licence conditions.

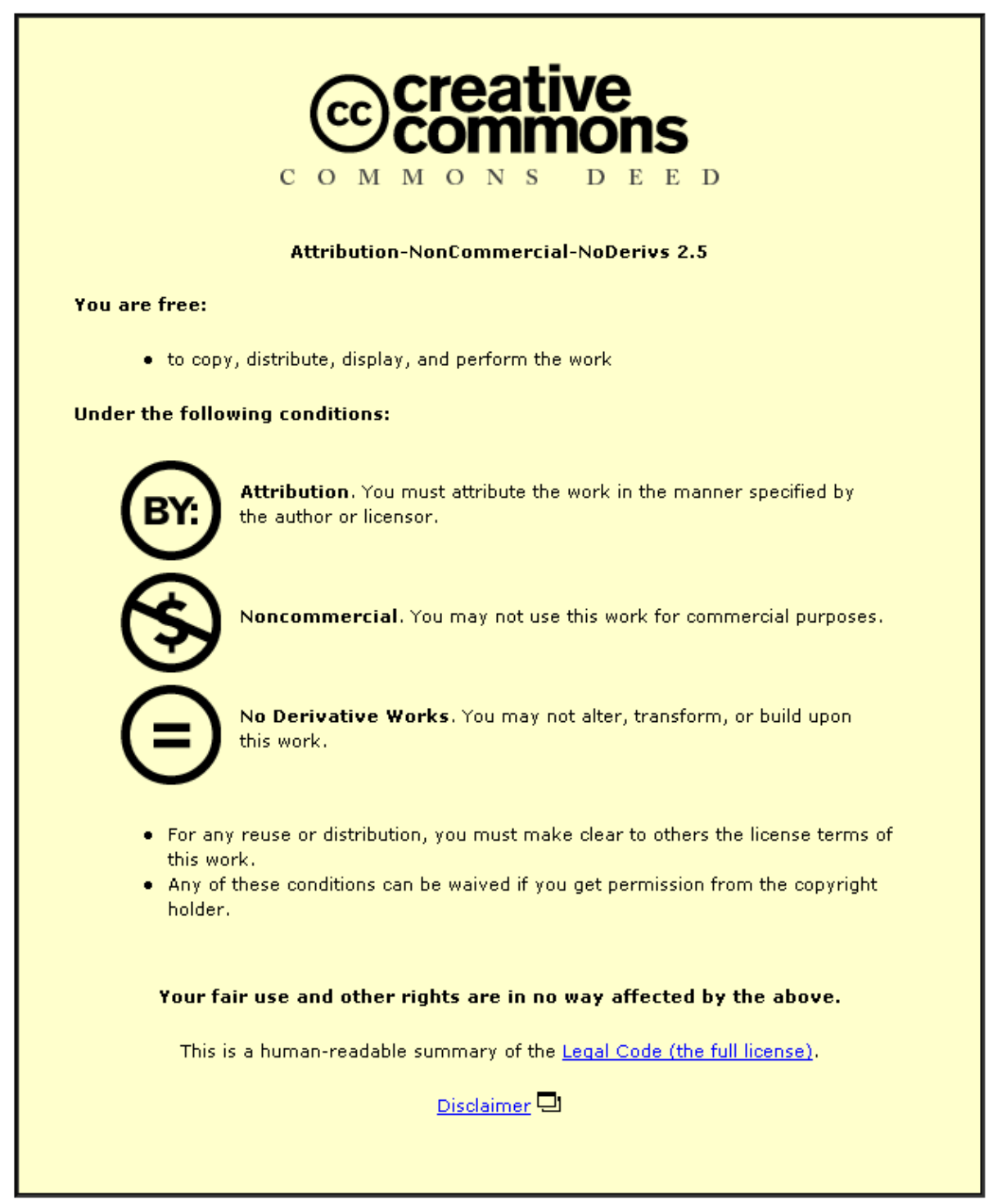

For the full text of this licence, please go to: http://creativecommons.org/licenses/by-nc-nd/2.5/ 


\title{
Capturing Volunteered Information For Inclusive Service Design: Potential Benefits And Challenges
}

\author{
Christopher J. Parker ${ }^{1}$, Andrew May ${ }^{2}$, Val Mitchell ${ }^{3}$, Alison Burrows ${ }^{4}$ \\ Loughborough Design School \\ Loughborough University, Loughborough, LE11 3TU \\ +44(0)1509226900 \\ ${ }^{1}$ [C.Parker ${ }^{2}$ [A.J.May $]^{3}$ [V.A.Mitchell] ${ }^{4}$ [A.B.Burrows] @lboro.ac.uk
}

\begin{abstract}
Inclusive Design focuses on understanding the broad spectrum of peoples' needs and abilities, with a view to developing more successful products and services. However, peoples' experiences with products and services are dynamic and multi-layered, presenting a unique set of challenges for Inclusive Designers. This paper presents the concept of Volunteered Geographic Information (VGI) as an integral part of future inclusive services. By utilising crowd-sourced data, services can become more efficient, intuitive and relevant for a wider population than previously possible. The potential benefits and challenges are presented and explored through a series of qualitative case studies. These focus on the differences in data generated by disabled and older people, and the uniqueness of the information gained. This type of information has the potential to provide a better match between user needs and service delivery, and enable the successful longer-term evolution of services.
\end{abstract}

KEYWORDS: Volunteered Geographic Information, inclusive service design, human factors, crowdsourcing

\section{INTRODUCTION}

The built environment frequently creates barriers for disabled people who are engaging in travel activities. Although great improvements have been made through high profile legislation - such as the Equality Act 2010 (Great Britain, 2010) and The Disability Discrimination Act 1995 (Great Britain, 1995) - access to the built environment and transport infrastructure remains an area of great concern (Ray and Ryder, 2003). Imrie and Kumar (1998) highlighted that under present practices a fully accessible built environment may be elusive. However, as demonstrated by Essex County Council's try a [bus/ train] days (Options for Independent Living, 2010), the experience of public transport for persons with disabilities is reliant on the effective and efficient implementation of services catering for a wide range of needs.

Although the concept of service provision is well established within business and marketing domains, Service Design has only recently emerged from Product Design as a separate discipline and practice (Kimbel, 2009). Whereas traditional product design focuses predominately on the interaction between a specific artefact and its user, Service Design considers the multiple touch points between the user and product and/or environment experienced over time (Saffer, 2006). This holistic approach (Stickdorn, 2010a) is particularly applicable to the design of public services such as transport and health, where users interact over time with a range of different stakeholders, physical and ephemeral products and environments in order to achieve their goals. Hence, from a Service Design perspective, ticket purchase, navigation of the station, encounters with staff and other passengers, finding a seat within a train carriage, and travel information all shape the overall experience of train travel. Additionally, the needs of the people engaging with this environment will vary not just 
from person to person, but over time too. Therefore, Service Design, including the opportunity for on-going improvement, potentially has much to offer as an approach to improving the inclusivity of existing transport services (Woodcock, 2003).

A key component of the Service Design approach is the direct participation of users in the process (Stickdorn, 2010b), often facilitated through the use of co-creation methods designed to enable users to participate as 'experts of their own experience' (Sanders and Stappers, 2008). This paper introduces to the Service and Inclusive Design communities the phenomena of Volunteered Geographic Information (VGI) as a potential route that enables direct contributions from users to enhance the inclusivity of transport services, and particularly as a means to enable consideration of the specific needs of older and disabled travellers.

\section{THE INCLUSIVITY OF VGI}

Previous research has demonstrated the advantages of including professionally generated data in service design, within the context of assessing the built environment for access issues (Porter et al., 2004). In contrast, Geographic Information (GI) can also be created by largely untrained volunteers, known as Volunteered Geographic Information or VGI. This is not restricted to traditional cartography, but to any point on earth where information may be assigned; e.g. restaurant reviews, travel logs, or geo-tagged photos (Goodchild, 2007a; Haklay et al., 2008; Pultar et al., 2009). VGI covers a diverse range of information types, extending from the generation of geographic features through to the contributions to data sets within the arts and human rights campaigns (Goodchild, 2007a; Burns, 2009; Kingsbury and Jones III, 2009), making it potentially highly suitable for adoption within service design. In particular, the anarchic nature of VGI allows for needs and issues which users find hard to verbalise to come to prominence in the data set, evoking co-ownership and long-term commitment (Parker et al., 2010).

Tracks4Africa $^{1}$ (Figure 1) allows volunteers to contribute, and edit a map of Africa, providing coverage of many aspects like roads, where to stay, eat, shop, fuel, money matters, emergencies and tourist locations. WheelMap ${ }^{2}$ (Figure 2 ) is essentially a custom render of OpenStreetMap ${ }^{3}$ that also allows wheelchair users to tag and comment on map features based on their accessibility. In both cases, the information presented is of direct relevance to groups of people with specific information needs, but crucially this is information that has never been available from any professional bodies. Examples of this might be physical barriers to service use at specific locations, such as high steps, or lack of trust by vulnerable users in service provision in a specific locality, due to unclear branding or signage. In these situations, the only people who are able to comment on such subjective matters are those who experience the disrupted service first hand, from a personal perspective: the volunteers.

\footnotetext{
${ }^{1}$ http://tracks4africa.co.za

2 http://wheelmap.org/en/

3 http://www.openstreetmap.org/
} 


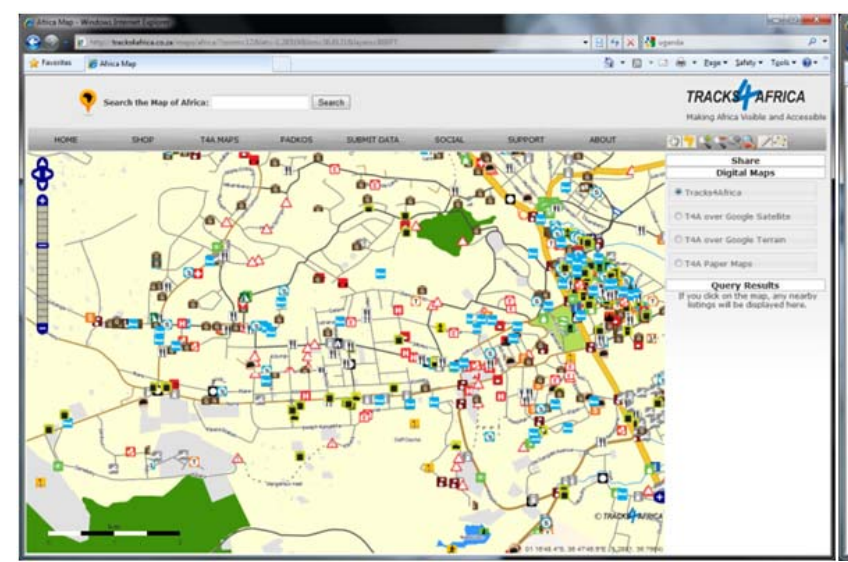

Figure 1 Tracks4Africa (Nairobi, Kenya)

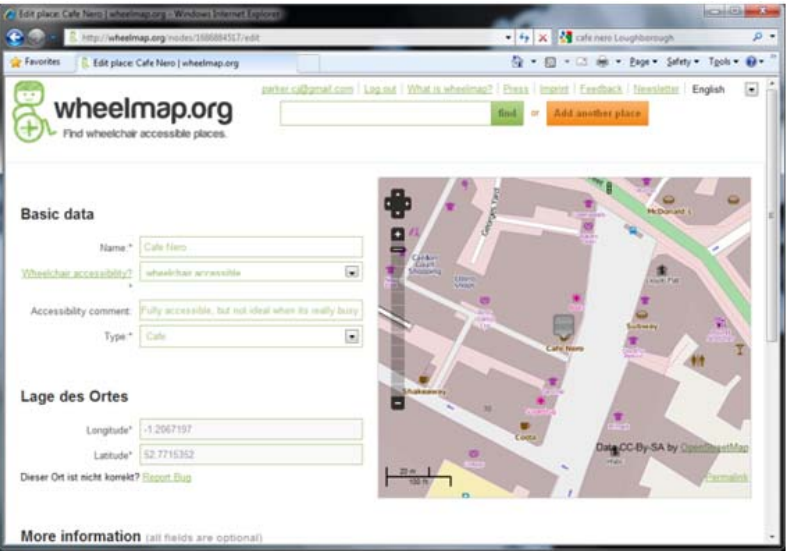

Figure 2 WheelMap (Loughborough, UK)

From a transport perspective, VGI can offer the following advantages:

- To understand the detailed needs of specific user groups where that information is sticky (Luthje et al., 2005), i.e. difficult for others outside of that user group to identify, collate and portray.

- To enable collection of data within a dynamic usage context, where experiences, barriers and opportunities may be transient.

- In particular, to enable wide ranging and relevant feedback on where service offerings at specific locations do not meet the needs of particular user groups, and where opportunities for on-going improvement exist.

\section{AIMS}

This paper describes three case studies that cover a breadth of services, capturing data in different ways:

- CASE STUDY 1: UNDERSTANDING THE UNIQUENESS OF VGI THROUGH MAP WALKS

- CASE STUDY 2: WILLINGNESS OF VOLUNTEERS TO CONTRIBUTE REAL TIME DATA ON TRANSPORT ISSUES

- CASE STUDY 3: THE NEED FOR ACCESSIBLE TOILET FACILITIES

These results are then taken forward into discussion to demonstrate the key potential benefits and challenges for VGI in relation to more inclusive service design. In particular, this paper aims to demonstrate that rather than being just an interesting example of co-design, VGI can help create and maintain inclusive services more effectively than is possible under traditional professional information schemes.

\section{CASE STUDY 1: UNDERSTANDING THE UNIQUENESS OF VGI THROUGH MAP WALKS}

This case study demonstrates some of the key differences between VGI and professionally generated data.

\section{METHODS}

This case study is based on the collection and analysis of volunteered data by travellers with specific needs, and the comparison with data currently available from professional sources. To understand the range of issues that wheelchair users can face when using public transport, it was important to incorporate as many different transport modes as possible. Involving people with genuine concerns in the realistic environment allowed for a genuine understanding of the user within a time sensitive and emotive context; as suggested by 
Stickdorn (2010b). Considering these factors, the following routes were selected for analysis of volunteered data:

- London Victoria to Stratford via London Waterloo (bus, underground)

- $\quad$ Stratford to Angel Islington via Bow Street (bus)

- $\quad$ Angel Islington to Greenwich via London Bridge (bus, train)

- Greenwich to London Bridge (DLR light rail)

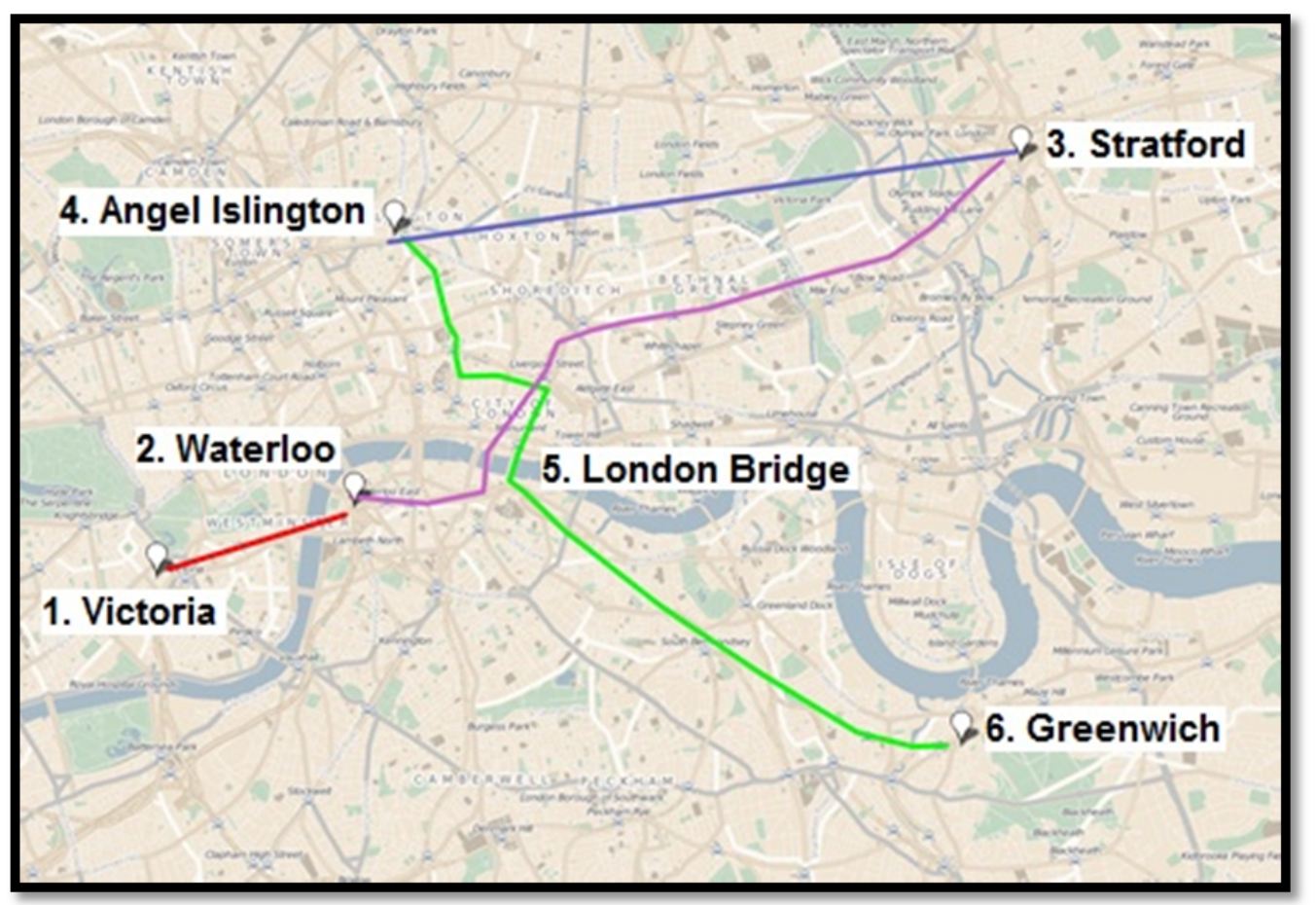

Figure 3 Data Collection With Participants During 'Map Walks'

Participants were accompanied individually around the transport route, having their thoughts and opinions relating to their location collected, in the style of Map Walks (Abley and Hill, 2005; Cinderby et al., 2006; Evans, 2009). For example, after going through a station or changing transport modes, they would be asked "is there anything about [name of last place] that you would wish to tell another wheelchair user who is visiting tomorrow?" Data was collected according to spatial distribution, ease of reaching the destination and the magnitude of the activities being undertaken (Handy and Niemeir, 1997). Five wheelchair users aged between 18 and 65 (and one assistant) were recruited, representing the minimum suggested number of volunteers describing a location to produce a high quality $\mathrm{VGI}$ data set (Bishr and Kuhn, 2007; Holone et al., 2007; Haklay et al., 2010).

In order for the professional information to be relevant to the study aims, it had to conform to the following specification:

- Structured GI produced by trained personnel (Fonseca and Sheth, 2002)

- Provide detailed GI that can be verified and integrated at a national level (Goodchild, 2007b)

- Carry a degree of professional authority; i.e. be from an official body (Coleman et al., 2009)

Professional Geographical Information (PGI) was collected from the most widely accessed 
sources relating to wheelchair travel in London, in order to give a comprehensive overview of the information currently available. Key literature was searched for information relating to the issue of wheelchair access at locations along the travel routes. Organisations such as Transport for London were also contacted to ensure that all information outlets and mediums easily accessible to untrained persons were captured.

\section{RESULTS}

Figure 4 shows key stages of volunteered data collection with the study participants.
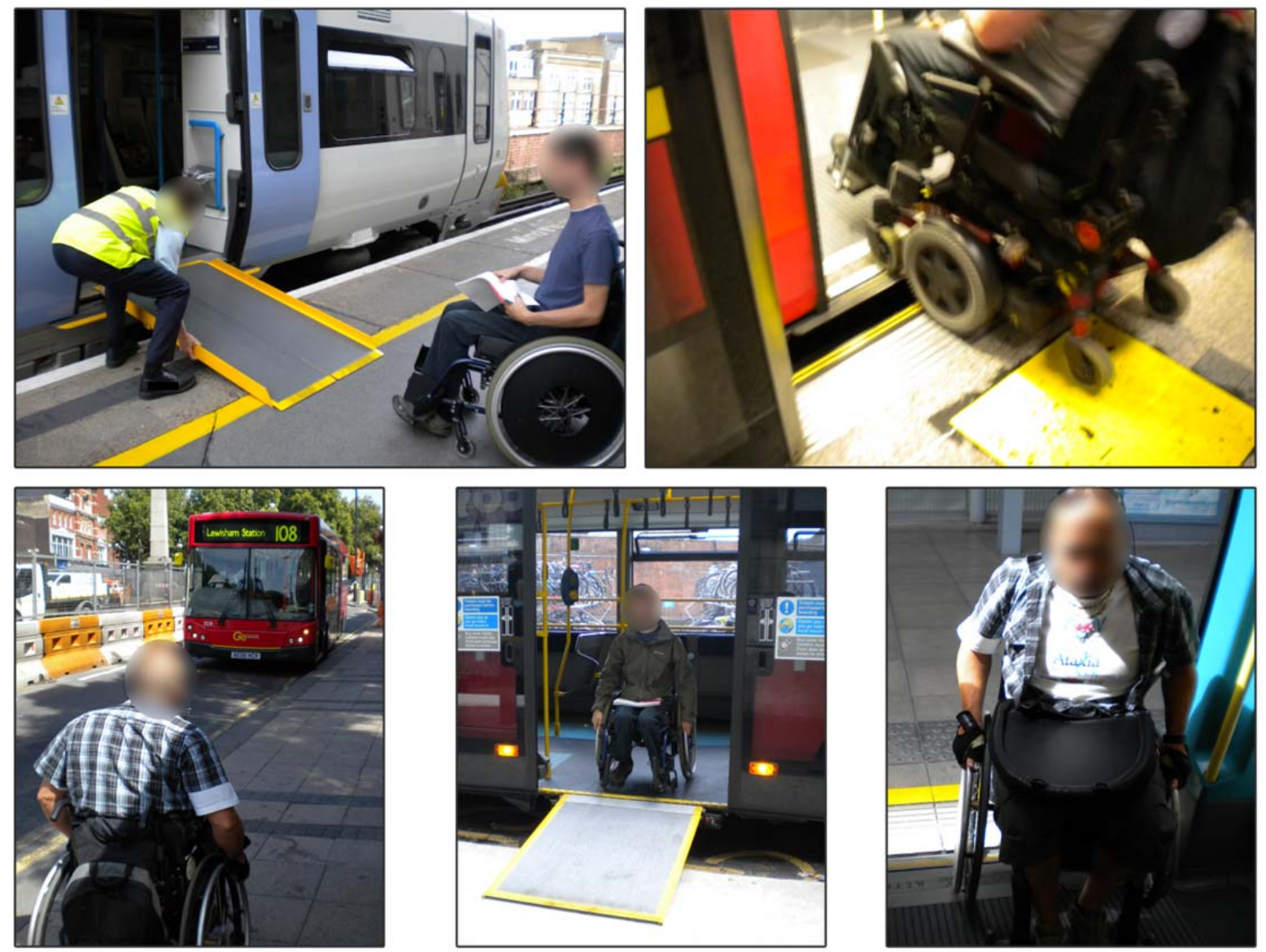

Figure 4 Data Collection with Participants During 'Map Walks'

The data from participants within this study were collated into Table 1. Issues identified more than once in the table represent multiple participant identification of that issue. The red strips provide a visualisation of the average severity of the access issue, with darker shades being more severe. 
Table 1 VGI Data Relating Wheelchair Access In London

\begin{tabular}{|c|c|c|c|c|c|c|c|c|}
\hline Location & Transport Area & Accessibility Issue & & & & & 5 & $\begin{array}{l}\text { Average } \\
\text { Severity }\end{array}$ \\
\hline \multirow[t]{2}{*}{ 1. London Victoria } & Bus Station & Lack of information & 0 & 1 & 0 & 0 & 0 & 2.0 \\
\hline & Train Station & Couldn't take train wanted & 0 & 0 & 1 & 0 & 0 & 3.0 \\
\hline \multirow[t]{3}{*}{ 2. London Waterloo } & Bus Station & Steep off ramp & 1 & 0 & 0 & 0 & 0 & 1.0 \\
\hline & On Tube & Train is very loud & 0 & 0 & 0 & 0 & 1 & 5.0 \\
\hline & Tube Station & Gap between train and platform difficult & 2 & 0 & 2 & 0 & 1 & 2.6 \\
\hline \multirow[t]{9}{*}{ 3. Stratford } & Bus Station & Ramp at off angle, bus had to adjust & 0 & 0 & 0 & 1 & 0 & 4.0 \\
\hline & & Steep ramp onto bus - needed help & 0 & 0 & 0 & 2 & 0 & 4.0 \\
\hline & & surfaces are irregular & 0 & 1 & 0 & 0 & 0 & 2.0 \\
\hline & On Bus & Bad information delivery & 0 & 0 & 0 & 2 & 0 & 4.0 \\
\hline & & Bell in bad position & 0 & 2 & 0 & 0 & 0 & 2.0 \\
\hline & & Worry about ramps not being deployed & 0 & 2 & 0 & 0 & 0 & 2.0 \\
\hline & Train Station & exit had deep gutter & 0 & 0 & 1 & 0 & 0 & 3.0 \\
\hline & & Lifts unmarked & 1 & 0 & 0 & 0 & 0 & 1.0 \\
\hline & & Smooth surfaces & 1 & 0 & 0 & 0 & 0 & 1.0 \\
\hline \multirow[t]{7}{*}{ 4. Bow Church } & Bus Stop 1 & Steep off-ramp & 0 & 0 & 1 & 0 & 0 & 3.0 \\
\hline & Bus Stop 2 & Bad information & 0 & 0 & 1 & 0 & 0 & 3.0 \\
\hline & & Steep ramp onto bus - needed help & 0 & 0 & 1 & 0 & 1 & 4.0 \\
\hline & On Bus & Bad Information & 2 & 0 & 0 & 0 & 1 & 2.3 \\
\hline & Walk & Drop Curb very difficult to pass & 2 & 2 & 0 & 1 & 1 & 2.5 \\
\hline & & Lack of accessible toilets & 0 & 1 & 0 & 0 & 0 & 2.0 \\
\hline & & Steep incline up hill & 0 & 0 & 1 & 0 & 0 & 3.0 \\
\hline \multirow[t]{5}{*}{ 5. Angel Islington } & Bus Stop 1 & Steep curbs around bus stop & 0 & 1 & 1 & 0 & 0 & 2.5 \\
\hline & & Steep off ramp & 1 & 0 & 0 & 0 & 0 & 1.0 \\
\hline & Bus Stop 2 & Steep Ramp & 0 & 0 & 1 & 0 & 0 & 3.0 \\
\hline & On Bus & No rear view mirror & 0 & 0 & 1 & 0 & 0 & 3.0 \\
\hline & & Not much room to move & 0 & 0 & 2 & 0 & 0 & 3.0 \\
\hline \multirow[t]{7}{*}{ 6. London Bridge } & Bus Station & not much room off ramp & 0 & 2 & 1 & 0 & 0 & 2.3 \\
\hline & & Waited 10 minutes for ramp & 0 & 0 & 0 & 1 & 0 & 4.0 \\
\hline & On Train & No wheelchair zone & 0 & 0 & 2 & 0 & 0 & 3.0 \\
\hline & Train Station & Had to change platforms to be accomodated & 0 & 2 & 0 & 0 & 0 & 2.0 \\
\hline & & Lack of information & 0 & 1 & 1 & 0 & 0 & 2.5 \\
\hline & & long steep tunnel - needed help & 0 & 0 & 1 & 1 & 1 & 4.0 \\
\hline & & Semi-steep ramp & 0 & 1 & 0 & 0 & 0 & 2.0 \\
\hline \multirow[t]{4}{*}{ 7. Greenwich } & Train Station & Drop curbs difficult to manage & 0 & 0 & 2 & 0 & 0 & 3.0 \\
\hline & & Lack of information & 0 & 0 & 0 & 0 & 2 & 5.0 \\
\hline & & Lifts very small & 0 & 0 & 0 & 0 & 2 & 5.0 \\
\hline & & Steep off ramp & 0 & 0 & 1 & 0 & 0 & 3.0 \\
\hline
\end{tabular}

Table 1 shows the diversity of experiences and opinions that may come from a single group of people who share a similar disability. Additionally, Table 1 clearly shows that, with an attributed severity of 5 , the worst problems experienced were the noise of the train (London Waterloo underground station) and lack of information (Greenwich train station). Other serious problems (average severity of 4 ) related to the position, inclination and availability of ramps (Stratford bus station, Bow Church bus stop and London Bridge bus station) and poor information delivery (on bus, Stratford). Problems reported to be moderately severe (2.5 to 3 on the scale) included architectural barriers, such as gaps, steep inclines or curbs, and the absence of a wheelchair area (London Bridge train).

PGI data about accessibility-related issues along the specified route was collected through sources such as Transport For London (TFL, 2010), South Eastern Rail (Southeastern, 2011) and Network Rail (Network Rail, 2011a); see Table 2. 
Table 2 PGI Data Relating To London Travel Wheelchair Accessibility; Specific Locations

\begin{tabular}{|c|c|c|c|}
\hline Location & $\begin{array}{l}\text { Transport } \\
\text { Mode }\end{array}$ & Describe The Access & Source \\
\hline $\begin{array}{l}\text { 1. London } \\
\text { Victoria }\end{array}$ & $\begin{array}{l}\text { Underground } \\
\text { Train Station }\end{array}$ & $\begin{array}{l}\text { No access to the underground for wheelchairs } \\
\text { Staff on hand to help } 24 \text { hours a day, } 7 \text { days a } \\
\text { week, wheelchairs always permitted. } \\
\text { Train access ramps available, best booked at } \\
\text { least } 24 \text { hours in advance. } \\
\text { Step free access through the station; not to } \\
\text { the underground. }\end{array}$ & $\begin{array}{l}\text { (TFL, 2010) } \\
\text { (Network Rail, } \\
\text { 2011b) }\end{array}$ \\
\hline 2. Waterloo & $\begin{array}{l}\text { Underground } \\
\text { Train Station }\end{array}$ & $\begin{array}{l}\text { Step between platform and the train }=50 \mathrm{~mm} \\
\text { Gap Between platform and the train }=70 \mathrm{~mm} \\
\text { Wheelchair access to the train and staff help } \\
\text { to be confirmed by station operator } \\
\text { Train access ramps available, best booked at } \\
\text { least } 24 \text { hours in advance. } \\
\text { Step free access through the station }\end{array}$ & $\begin{array}{l}\text { (TFL, 2010) } \\
\text { (Network Rail, } \\
\text { 2011c) }\end{array}$ \\
\hline 3. Stratford & Underground & $\begin{array}{l}\text { Step between platform and the train }=50 \mathrm{~mm} \\
\text { Gap Between platform and the train }=78- \\
85 \mathrm{~mm}\end{array}$ & (TFL, 2010) \\
\hline $\begin{array}{l}\text { 4. Angel } \\
\text { Islington }\end{array}$ & Underground & No access to the underground for wheelchairs & (TFL, 2010) \\
\hline $\begin{array}{l}\text { 5. London } \\
\text { Bridge }\end{array}$ & Train Station & $\begin{array}{l}\text { Staff on hand to help 04:00 - 01:00, } 7 \text { days a } \\
\text { week, wheelchairs always permitted. } \\
\text { Train access ramps available, best booked at } \\
\text { least } 48 \text { hours in advance. } \\
\text { Step free access through the station }\end{array}$ & $\begin{array}{l}\text { (Network Rail, } \\
\text { 2011a) }\end{array}$ \\
\hline 6. Greenwich & Train Station & $\begin{array}{l}\text { Staff help Monday-Friday 06:00-21:30, } \\
\text { Saturday 06:00-21:30, Sunday 06:00-21:30 } \\
\text { Station is step free } \\
\text { Train access ramps available, ask staff } \\
\text { Wheelchair access to be confirmed by station } \\
\text { operator }\end{array}$ & $\begin{array}{l}\text { (Southeastern } \\
\text {, 2011) }\end{array}$ \\
\hline
\end{tabular}

It can be seen that there are fundamental differences between the VGI and the PGI, and this is discussed below.

\section{CASE STUDY 2: WILLINGNESS OF VOLUNTEERS TO CONTRIBUTE REAL TIME DATA ON TRANSPORT ISSUES}

This case study gives an insight into the wide range of data that can be contributed by members of the public. It is based on the use of www.FixMyTransport.com by the general public. This is a web-based tool developed by mySociety that enables travellers to report issues encountered with the transport service. A key feature is that the web interface is designed to work on mobile devices, and can also use GPS and cell-based positioning to identify the traveller's location. Travellers therefore have the opportunity to volunteer data relating to the performance of the transport service, either as specific issues are encountered, or later at their convenience. The overall aim of FixMyTransport is to empower individual travellers to provide critical feedback on transport service provision, in order to get common transport problems solved by the operators responsible.

When an individual reports a problem using FixMyTransport, they initially state whether the issue is to do with either a stop, station, journey or route. For a stop or station, they select a location (or have this determined automatically) and then the specific item of interest. For a journey or route, they select the mode of transport and then the specific route. The traveller 
can then describe what the issue was, and the website directs their comment to the relevant responsible body (e.g. specific train operator, or local council). The site encourages individuals to both (1) volunteer issues, and (2) support existing campaigns.

\section{METHOD AND RESULTS}

The data summary for this case study comes from a log of 750 volunteered contributions by members of the travelling public. Therefore under the definition of Alonso et al. (2008) this may be considered an example of crowd sourced data: "taking a job traditionally performed by a designated agent and outsourcing it to an undefined, generally large group of people in the form of an open call".

Table 3 Categorisation of issues volunteered by FixMyTransport contributors, by frequency

\begin{tabular}{ll|ll}
\hline Issue & $\mathbf{N}=$ & Issue & $\mathbf{N}=$ \\
\hline Lack of information & 88 & Rude staff & 20 \\
Station facilities & 76 & Bus stop location & 19 \\
Timetables & 64 & Bus not stopping & 17 \\
Overcrowding & 58 & Vandalism/graffiti & 16 \\
Late/non-arriving bus & 48 & Temperature & 15 \\
$\begin{array}{l}\text { Late/non-arriving } \\
\text { train }\end{array}$ & 42 & Train facilities & 13 \\
Bus stop facilities & 34 & Bike parking & 12 \\
Fares/tickets & 33 & Noise & 11 \\
Dirt/litter & 28 & Station access & 11 \\
Route & 25 & Toilets & 11 \\
$\begin{array}{l}\text { Accessibility - } \\
\text { stations }\end{array}$ & 23 & Car parks & 10 \\
\hline
\end{tabular}

The table above shows the wide diversity of data that can be obtained from passengers. As well as the 22 categories above, there were a further 76 out of an overall sample of 750 that fell into an additional 'other' category (comprising at least another 15 different categories of issues).

\section{CASE STUDY 3: THE NEED FOR ACCESSIBLE TOILET FACILITIES}

This section considers the case of accessible toilets in the built environment, and how VGI may provide a vital contribution to the inclusive services offered within the UK. In order to illustrate this consideration, the small fishing village of Mevagissey (Cornwall, UK) was selected. This case study was based on an examination of various toilet facility information projects for disabled persons, and the benefit which VGI enhanced services may offer such persons.

In an investigation into incontinence and wheelchair users, Lynch et al. (2000) demonstrated that $56.1 \%$ of wheelchair users were affected, with $4.7-11.5 \%$ of those being constantly 
affected in their everyday lives. Additionally, and as testament to the prevalence of this issue, $25-28 \%$ of women between the ages of 20 and 59 are affected by continence issues (Samuelsson et al., 1997; Hägglund and Wadensten, 2007; Hannestad et al., 2000). As a result, people managing continence concerns may experience feelings of shame, social exclusion and reluctance to venture outside into unknown areas of the built environment (Verhoef et al., 2005; Hägglund and Wadensten, 2007). It is not enough to simply provide adequate and accessible toilet facilities, since their locations, adequacy and accessibility must also be effectively communicated (Knight and Bichard, 2011).

In a report into the public accessibility of toilets, Knight and Bichard (2011) highlighted how, although information on the location of toilets is available, it is seldom available on common cartography (Figure 5) and is confined to specialist guides and/or maps. Currently, no publicly available professional information on accessible toilets is available for Mevagissey. However, over recent years there has been a surge of interest in county councils making this information available through open data, meaning that members of the public may access and utilise the information as they see fit, without paying any fees, yet cannot edit the data itself. This has led to the development of websites such as The Great British Public Toilet Map (Knight and Bichard, 2012) presenting open data on accessible public toilets, a model which in all feasibility could be made available on a national rather than regional level; see Figure 6.

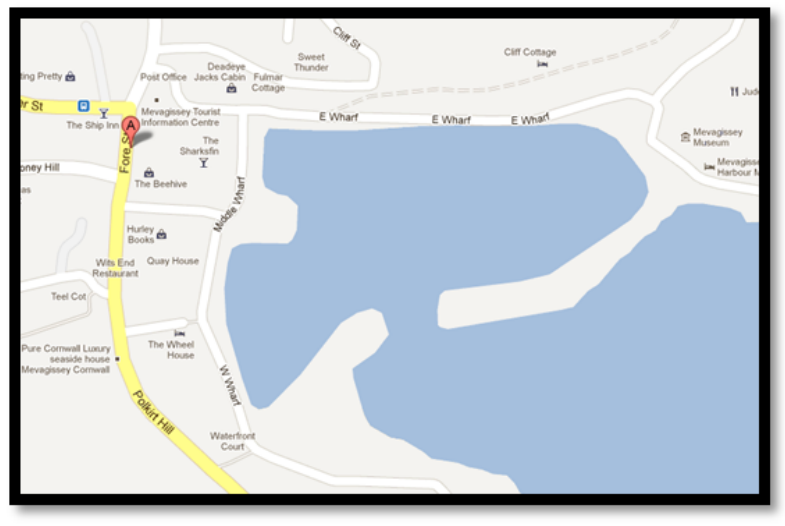

Figure 5 Mevagissey Harbour as shown on Google Maps (๑ Google, 2012)

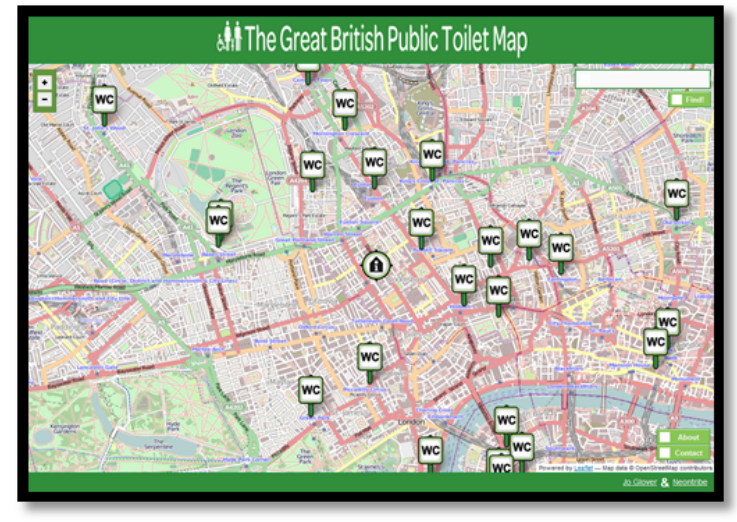

Figure 6 Wheelchair accessible toilets in London as shown on The Great British Public Toilet Map; TGBPTM (Knight and Bichard, 2012)

Knight and Bichard (2011) highlighted how the access to the toilet facilities extends beyond the facility itself and into the surrounding area (e.g. barriers preventing access to the toilet), the condition of the toilet facilities (e.g. cleanliness) and their entrance fee. Many cafes and stores also provide accessible toilets, and being privately operated would not appear on professional information data sets. Additionally, the number and condition of toilets change over time. When this is considered alongside the often limited currency of the professional information (Parker et al., 2012a), it shows the traditional reliance on professional data sources may be of limited utility in this specific instance. 


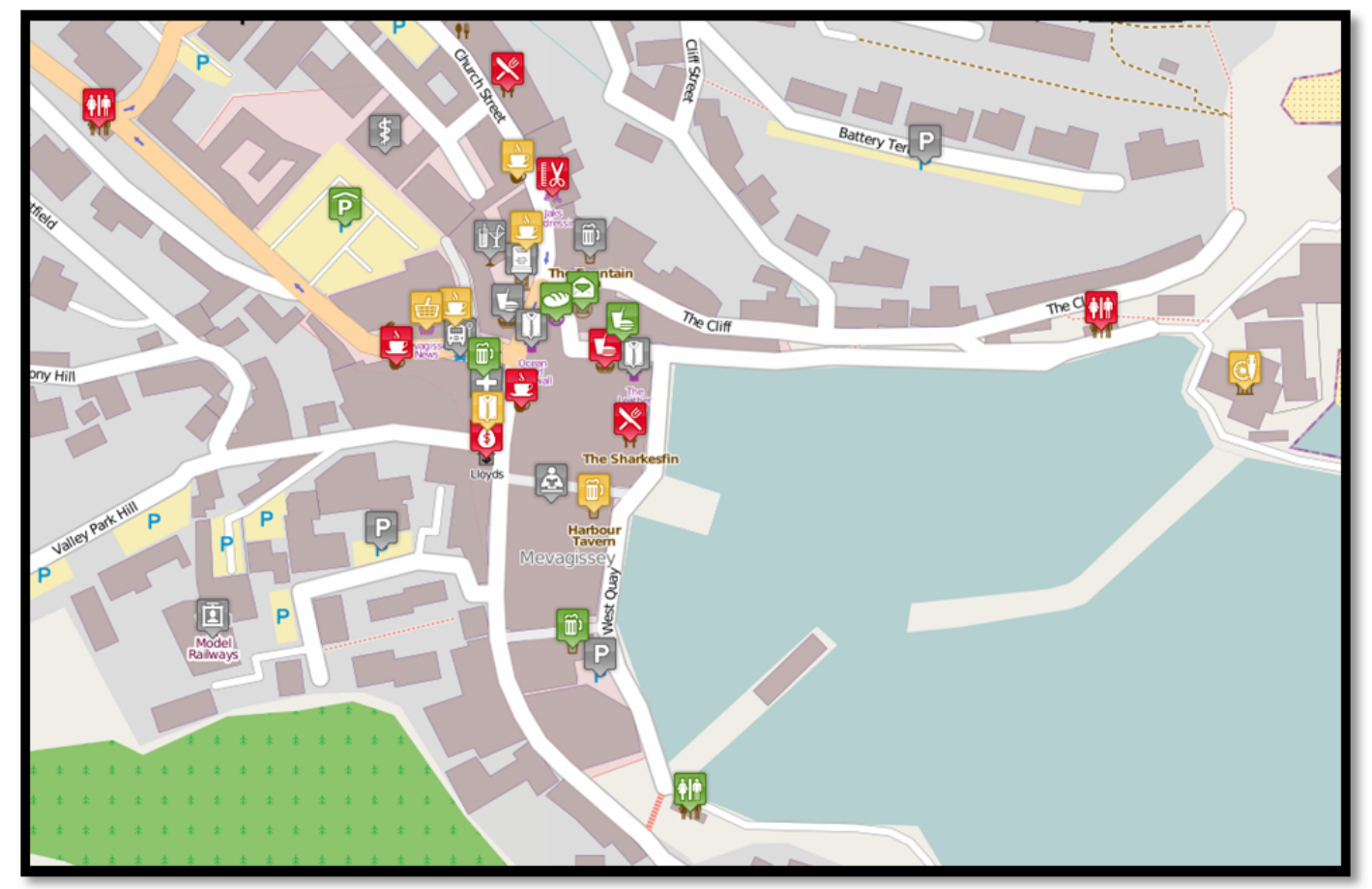

Figure 7 A Wheelchair Specific Access Map; Mevagissey, Cornwall (WheelMap, 2012)

In recent years, VGI projects such as ToiletMap (www.toiletmap.co.uk) and WheelMap (www.wheelmap.org) which address such issues have begun to emerge. Here, members of the public (predominantly wheelchair users) tag facilities and amenities for their accessibility and ability to provide toilet facilities via the criteria set out in Table 4.

Table 4 Accessibility Tagging Criteria (WheelMap, 2012)

\begin{tabular}{l|l}
\hline Degree of Access & Description of Access Conditionals \\
\hline Accessible & $\begin{array}{l}\text { Entrance without steps, all rooms without steps, accessible } \\
\text { toilet if customary in a place }\end{array}$ \\
\hline Limited Access & $\begin{array}{l}\text { Entry has a step (max. height } 7 \mathrm{~cm} \text { ), most rooms are without } \\
\text { steps, toilet is not accessible }\end{array}$ \\
\hline No Access & Entry has steep or several steps, rooms are not accessible \\
\hline
\end{tabular}

Figure 7 shows the main location of shops and facilities in the village to be just behind the harbour with toilets available to the northeast, west and south. Given a standard map of public toilets, a wheelchair user would have to guess which toilet to go for, all the while not knowing if it would be accessible when they arrive there, and unknowingly having a 2 in 3 chance of getting it wrong with a long trip to the next toilet (1 in 2 chance of selecting the correct one). However, with the VGI map not only can the correct public toilet be identified, but also the closest private toilet can be located.

Specifically, VGI in this context can enhance the value of an information service in a number of ways:

- All locations which may provide toilet facilities can be included in the mashup (geolocated information overlaid onto an interactive map), providing a potentially complete 
picture of accessibility,

- As pubs, restaurants, and cafes (etc.) become more or less accessible, the data may be updated instantly to reflect this condition by visitors to the establishment

- As data is being added to the open source OpenStreetMap resource, there are no restrictions on the dimensions of data which can be volunteered and represented (e.g. entrance fee, number of toilets),

- Wheelchair user-volunteers experience the facilities in ways not possible for the casual surveyor, allowing qualitative data about the facilities overall suitability for their needs to be contributed,

- Cheaper data collection and maintenance costs for the service provider, as contributors are not financially rewarded for their work.

This case study shows how building VGI into a wheelchair user information service therefore goes beyond the co-creation of services with users and designers (Stickdorn and Schneider, 2010). Instead, it provides the opportunity for the inclusivity of services to be increased by designing in the capability for users to contribute data that enables the service to evolve and dynamically adapt to the needs of specific user groups. Yet in contrast (and as a different model), Knight \& Bichard's (2012) Great British Public Toilet Map (GBPTM) utilises open data generated by local authorities but which allows members of the public to comment and provide feedback on the data. This includes user rating and review provision so people know what to expect (ibid, 2012; 33). Indeed, the GBPTM shows how PGI and VGI can be brought together.

\section{DISCUSSION}

\section{VGI CAN PRODUCE A BETTER UNDERSTANDING OF PEOPLES' NEEDS}

Although not shown in detail within Table 1, the ways in which the participants experienced the environment (describing negative features in terms of their severity) varied from person to person. For example, while one participant in a manual chair was able to navigate a series of obstacles around London Bridge station, another participant in a similar chair found them very difficult to navigate without aid. In contrast, none of the PGI (Table 2) reflected such variances, leaving the reader to assume that the built environment would either prohibit access or offer no challenge. Further comparison of Table 1 and Table 2 suggests that the content itself does not necessarily have to come from disabled travellers. The information relating to ramps, inclines and obstructions could also be collated by professional sources i.e. there is nothing intrinsic to that information that requires it to be generated by volunteers. However, the subjective assessment of those attributes (e.g. 'steep') and the impact on the individual (e.g. 'difficult to pass') are very dependent on the capabilities of the individual, and these would be more difficult for a professional contributor to describe in a meaningful manner. This in in line with Parker et al. (2012a) - that one of the key advantages of VGI for the user is capturing information that only comes from persons experiencing the phenomenon first hand. This perspective is also supported by the observation that the most severe issues collected through VGI were not addressed by PGI. For example, the loudness of the train, steepness of ramps and the general lack of on-location information. To say that either VGI or PGI is better than the other would be unsuitable at this stage. Instead, this indicates the distinct benefits of each, to the user, which if fully understood may allow the correct information ( $\mathrm{VGI}$ or $\mathrm{PGI}$ ) to be used at the right time and in the right situation.

The PGI in Table 2 was stated in objective terms, where appropriate - for example, gaps between trains and platforms were quantified. Table 1 shows how the information generated by the volunteers was typically described in a more subjective manner, with frequent use of terms such as 'steep' and 'difficult'. The format of the VGI is therefore consistent with the physical and emotional impact of the environment upon the disabled traveller. The specific contribution of VGI to inclusive design lies in its capacity to generate rich empathic data. The 
qualitative experiential information it can generate, as well as immediate access to user feedback, provides fertile material for designers to create new design concepts and refine existing solutions.

The importance of case study two is that the results are fully complementary with those of case study one. This is despite the two groups of people being separated by geography and physical abilities. This ability for VGI to add richness to the data set (as discussed within this paper) was originally presented by Goodchild (2007b) who postulated the use of the world's six billion inhabitants as sensors to make up for this shortcoming in traditional GI. That is, a lack of current and comprehensive data with an ever increasing consumer appetite for more specialised geo-information not covered by traditional professional bodies. Goodchild (2007a) commented that VGI is able to provide information at a faster rate than traditional mediums, filling a long-standing gap in geographic information delivery (Crone, 1968; Wood, 2003). However, Parker et al. (2010) showed that consumers (those who primarily utilise) and Special Interest Groups (those who primarily contribute) are fundamentally different in their attitudes towards and relationship with VGI products. In particular, the producers of VGI value it as an exceptional source of information, professionals are sceptical of its abilities and consumers are open minded to its benefits, but it has to be clearly better than other information currently available for them to adopt it. Consequently, while almost anyone can contribute data (Goodchild, 2007b; Shirky, 2009), only a self-nominated minority will, as highlighted by Parker et al. (2012a). However, the degree to which this impacts the utility of VGI is debatable, since small numbers of contributors may make large and effective data sets (Bishr and Kuhn, 2007; Haklay et al., 2010).

\section{VGI CAN ALLOW FOR ONGOING DATA COLLECTION AND SERVICE REVISION}

Since the emergence of Web 2.0, a new approach to the commerce model has emerged based on utilising the power of the crowd's intelligence and openness. Such principals of peer participation have already been demonstrated to be faster, more efficient and more innovative than traditional inward looking models (Tapscott and Williams, 2008). Therefore, the application of volunteered information to inclusive service design is more than a rationalised proposal - it is a logical extension of a proven established methodology. Specifically, the three most prominent benefits to service design coming from the inclusion and utilisation of VGI are:

- Systems are robust and flexible enough to evolve with temporal changes in the environment not envisioned during the service design period (Parker et al., 2012a). This is testified by the development of OpenStreetMap following the 2010 Haiti Earthquake (Zook et al., 2010).

- Volunteered information provides a cheap and effective solution to the costly transfer of professional information, often referred to as sticky (Luthje et al., 2005).

- Providing contributors to Special Interest Groups and Local Communities with a sense of empowerment, producing a close affinity between the user and the service that the VGI is an integral element of (Parker et al., 2010).

In addition for inclusive service design, the foremost challenge associated with the utilisation of VGI to provide long standing, flexible and efficient services should not be considered a technical one (Turner, 2006) but instead one of user engagement. Namely, encouraging people with a range of capabilities, including long-term wheelchair users and less mobile travellers, not only to contribute their experience once, but to keep contributing regularly whilst editing the contributions of others.

There is also an opportunity for designers to develop the tools that people use to contribute their information. While GPS-enabled smartphones and the emergence of smartphone apps have gone some way towards allowing the public to contribute to VGI (e.g. the WheelMap 
app), a number of limitations still exist. There is already a considerable tradition of research into making mobile phone design more inclusive, but there is now a further need to design services (apps or others) that will encourage everyday VGI and support its role as a tool for inclusive design. An example of a step in this direction from within the UK is the 'FixMyTransport' service described in case study two. Through the provision of an easy to use web (and mobile compatible) user interface, data from members of the public (and not just those with a special interest in a topic or campaign) can be collected, producing a wealth of data on a wide range of topics. While the anarchic nature of VGI means that it can be hard to control or predict at times (Budhathoki et al., 2008), this uniqueness can be considered one of the defining strengths of VGI in delivering inclusive services.

\section{VGI PRODUCES UNIQUE INFORMATION OUTSIDE THE SCOPE OF PROFESSIONALS}

In comparing the VGI (Table 1) and the PGI (Table 2) data, it is clear that there were some key differences between the VGI generated by the study participants, and the PGI available from the official information sources. The PGI tended to focus on what general help from staff or additional resources (e.g. ramps) was available, although there was also some information related to the gap between the platform and the train. In contrast, the VGI focused on the detail at specific locations that had an impact on the ability of the individual to complete a journey successfully. The VGI in case study one highlight the lack of information, physical obstructions such as gutters and raised obstructions, and in particular, issues to do with accessing amenities and areas via ramps and steps. The content generated by the volunteers was more detailed, geographically specific, and relevant to the individual. As case study three presents, a wide range of issues not covered by traditional media can be generated through people volunteering their concerns. While some of these could be assessed via advanced professional methodologies - such as HADRIAN (Porter et al., 2004) - their subjective nature and interpretation highlight how the information can only, or most accurately, come from volunteer contributors.

The benefits of presenting such subjective information to users should be clear to all designers. People can relate to it in a personal way, understanding the variety of subtle range of opinions as judged against their personal experience. Consideration should therefore be given to the presentation of $\mathrm{VGI}$ alongside $\mathrm{PGI}$, in a way that utilises the benefits of both. Doing so would allow designers to create services that are more functional, efficient and satisfying, utilising information qualities not available through traditional mediums.

Parker et al. (2012b) demonstrated how tangible and significant benefit can be derived from VGI when it is utilised alongside PGI. An explanation for this may be derived from Parker et al. (2012a) and Schuett (1993), who demonstrated that in risk management situations, user's utilise multiple information sources to converge on a truth. This was the result of the user requiring confirmation from multiple angles, and the utilisation of each information source to fulfil their emotional requirements and concerns. This is because each information source includes different characteristics relative to the user's needs (Elwood, 2008; Zielstra and Zipf, 2010).

This demonstration that combined professional and volunteered sources are more beneficial to the users holistic needs than either source on its own has significant implications for the design of inclusive services. A satisfying user experience requires more than the fulfilment of a person's information needs. It also requires peoples' experiences to be considered as subjective, situated, complex and dynamic (Hassenzahl and Tractinsky, 2006). VGI is a democratic vehicle for communicating and sharing a plethora of user experiences. While it may in (some contexts) lack the more authoritative credibility of PGI, the integrity of VGI stems from the richness obtained through real life accounts of the environment, experienced 
and contributed by people, and for people.

\section{CONCLUSION}

Philippe Starck (2012) said: "design is a tool to help the tribe". This paper has presented a new way of thinking about service design, one built on the long-term inclusion of volunteered information, democratising the service design into an efficient, flexible and ecological output. The strength of this approach lies in the ability of people to contribute unique information (which may be hard to verbalise through traditional mediums) as the needs of society and the user's engagement with the environment changes over time, evoking co-ownership and longterm commitment (Parker et al., 2010). Furthermore, provided the technological means exist and user interfaces are accessible, there is no restriction as to who can contribute to VGI. Indeed this paper has explored how understanding the needs of disable or vulnerable people through VGI could foster significant design improvements to transport, either via top-down development or via bottom up or 'grass-roots' innovation (Ross et al., 2012). Every contribution has the potential to be a micro-iteration of change in a service's evolution, keeping it relevant and beneficial to a higher degree for a longer period of time. Making use of such open source standard means that a service has the potential to be accessible to a global audience, rather than the select and specific few.

\section{REFERENCES}

Abley, S. and Hill, S. (2005). Designing living streets: a guide to creating lively, walkable neighbourhoods,. London, UK: Transport Research Laboratory (TRL).

Alonso, O., Rose, D.E. and Stewart, B. (2008). 'Crowdsourcing for relevance evaluation'. ACM SIGIR Forum, 42(2): 9-15.

Bishr, M. and Kuhn, W. (2007). 'Geospatial Information Bottom-Up: A Matter of Trust and Semantics'. In S. Irina-Fabrikant \& M. Wachowicz, eds. The European Information Society. Springer Berlin Heidelberg, pp. 365-387.

Budhathoki, N.R., Bruce, B. (Chip) and Nedovic-Budic, Z. (2008). 'Reconceptualizing the role of the user of spatial data infrastructure'. GeoJournal, 72(3): 149-160.

Burns, R.L. (2009). Spatializing Places, People, and Utterances: A Case Study Involving San Diego Neighborhoods. San Diego, USA: San Diego State University.

Cinderby, S., Forrester, J. and Owen, A. (2006). 'A personal history of participatory geographic information systems in the UK context: Successes and failures and their implications for good practice'. In L. McDowell, ed. Royal Geographical Society Annual Conference. London, UK: RGS-IBG.

Coleman, D.J., Georgiadou, Y. and Labonte, J. (2009). 'Volunteered Geographic Information: The Nature and Motivation of Produsers'. International Journal of Spatial Data Infrastructures Research, 4: 332-358.

Crone, G.R. (1968). Maps and their Makers: an introduction to the history of cartography W. G. East, ed.,. London, UK: Hutchinson \& Co LTD.

Elwood, S. (2008). 'Volunteered geographic information: future research directions motivated by critical, participatory, and feminist GIS'. GeoJournal, 72: 173-183. 
Evans, G. (2009). 'Accessibility, Urban Design and the Whole Journey Environment'. Built Environment, 35(3): 366-385.

Fonseca, F. and Sheth, A. (2002). 'The Geospatial Semantic Web'. UCGIS: 1-2. Available at: http://www.ucgis.org/priorities/research/2002researchPDF/shortterm/e_geosemantic_we b.pdf [Accessed October 30, 2012].

Goodchild, M.F. (2007a). 'Citizens as Sensors: The world of Volunteered Geography'. GeoJournal, 69(4): 211-221.

Goodchild, M.F. (2007b). 'Citizens as Voluntary Sensors: Spatial Data Infrastructure in the World of Web 2.0'. International Journal of Spatial Data Infrastructure Research, 2: 2432.

Google. (2012). 'Google Maps'. maps.google.co.uk. Available at: http://tinyurl.com/MevagisseyHarbour [Accessed October 30, 2012].

Great Britain. (1995). Disability Discrimination Act 1995,. London, UK: The Stationery Office.

Great Britain. (2010). Equality Act 2010,. London, UK: The Stationery Office.

Haklay, M., Basiouka, S., Antoniou, V. and Ather, A. (2010). 'How Many Volunteers Does It Take To Map An Area Well? The Validity of Linus' Law to Volunteered Geographic Information'. The Cartographic Journal, 47: 315-322.

Haklay, M., Singleton, A. and Parker, C. (2008). 'Web mapping 2.0: the Neogeography of the Geoweb'. Geography Compass, 2(6): 2011-2039.

Handy, S.L. and Niemeir, D.A. (1997). 'Measuring Accessibility, An Exploration of Issues and Alternatives'. Environment and Planning A, 29: 1175-1194.

Hannestad, Y.S., Rortveit, G., Sandvik, H. and Hunskaar, S. (2000). 'community- based epidemiological sutvey of female urinary incontinence: the Norwiegen EPINCONT study. Epiodemiology of incontinence in the county of Nord-Trodelag'. Journal of Clinical Epiodemiology, 53: 1150-1157.

Hassenzahl, M. and Tractinsky, N. (2006). 'User Experience - a research agenda'. Behaviour \& Information Technology, 25: 91-97.

Holone, H., Misund, G. and Holmstedt, H. (2007). 'Users Are Doing It For Themselves: Pedestrian Navigation With User Generated Content'. In K. Al-Begain, ed. NGMAST 2007: International Conference on Next Generation Mobile Applications, Services and Technologies. Cardiff, UK: IEEE, pp. 91-99.

Hägglund, D. and Wadensten, B. (2007). 'Fear of humiliation inhibits women's care-seeking behaviour for long-term urinary incontinence'. Scandinavian Journal of Caring Sciences, 21: $305-312$.

Imrie, R. and Kumar, M. (1998). 'Focusing on disability and access in the built environment'. Disability \& Society, 13: 357-374. 
Kimbel, L. (2009). 'The Turn to Service Design'. In G. Julier \& L. Moor, eds. Design and Creativity: Policy, Management and Practice. New York, USA: Berg, pp. 157-173.

Kingsbury, P. and Jones III, J.P. (2009). 'Walter Benjamin's Dionysian Adventures on Google Earth'. Geoforum, 40(4): 502-513.

Knight, G. and Bichard, J.-A. (2011). Publically Accessible Toilets: an inclusive design guide,. London, UK: Royal College of Art.

Knight, G. and Bichard, J.-A. (2012). 'The Great British Public Toilet Map'. GreatBritishPublicToiletMap.rca.ac.uk. Available at:

http://greatbritishpublictoiletmap.rca.ac.uk/ [Accessed October 30, 2012].

Luthje, C., Herstatt, C. and Von Hippel, E. (2005). 'User-innovators and local information: The case of mountain biking'. Research Policy, 34(6): 951-965.

Lynch, A.C., Wong, C., Anthony, A., Dobbs, B.R. and Frizelle, F.A. (2000). 'Bowel dysfunction following spinal cord injury: a description of bowel function in a spinal cordinjured population and comparison with age and gender matched controls'. Spinal Cord, 38(12): 717-723.

Network Rail. (2011a). 'London Bridge'. nationalrail.co.uk, 2011. Available at: http://www.nationalrail.co.uk/stations/lbg/details.html [Accessed August 11, 2011].

Network Rail. (2011b). 'London Victoria'. nationalrail.co.uk. Available at: http://www.nationalrail.co.uk/stations/vic/details.html [Accessed August 11, 2011].

Network Rail. (2011c). 'London Waterloo'. nationalrail.co.uk. Available at: http://www.nationalrail.co.uk/stations/wat/details.html [Accessed August 11, 2011].

Options for Independent Living. (2010). Using Public Transport With Choice, Control and Confidence,. Chelmsford, UK: Essex County Council.

Parker, C.J., May, A.J. and Mitchell, V. (2010). 'An Exploration of Volunteered Geographic Information Stakeholders'. In M. Haklay, J. Morley, \& H. Rahemtulla, eds. Proceedings of the GIS Research UK 18th Annual Conference. University College London: UCL, pp. 137-142.

Parker, C.J., May, A.J. and Mitchell, V. (2012a). 'Understanding Design with VGI using an Information Relevance Framework'. Transactions in GIS, 16(4): 545-560.

Parker, C.J., May, A.J. and Mitchell, V. (2012b). 'Using VGI To Enhance User Judgements Of Quality And Authority'. In D. Whyatt \& B. Rowlingson, eds. Proceedings of GIS Research UK 20th Annual Conference. Lancaster, UK: GIS Research UK, pp. 171-178.

Porter, J.M., Case, K., Marshall, R., Gyi, D., Simms, R. and Olivera, N. (2004). 'Beyond Jack and Jill: designing for individuals using HADRIAN'. International Journal of Industrial Ergonomics, 33(3): 249-264.

Pultar, E., Raubal, M., Cova, T.J. and Goodchild, M.F. (2009). 'Dynamic GIS case studies: Wildfire evacuation and volunteered geographic information'. Transactions in GIS, 13: 85-104. 
Ray, N.M. and Ryder, M.E. (2003). "'Ebilities'” tourism: an exploratory discussion of the travel needs and motivation of the mobility-disabled'. Tourism Management, 24: 57-72.

Ross, T., Mitchell, V. and May, A.J. (2012). 'Bottom-up grassroots innovation in transport: motivations, barriers and enablers'. Transportation Planning and Technology Management, 35: 469-489.

Saffer, D. (2006). Designing for Interaction: Creating Smart Appliances and Clever Devices,. Berkeley, USA: Peachpit Press.

Samuelsson, E., Victor, A. and Tibblin, G. (1997). 'A Population study of urinary incontinence and nocturia among women 20-59. Prevelance, well being and wish for treatment'. Acta Obstetricia et Gynecologica Scandinavica, 76: 74-80.

Sanders, E. and Stappers, P.J. (2008). 'Co-creation and the new landscapes of design'. CoDesign, 4: 5-18.

Schuett, M.A. (1993). 'Information sources and risk recreation: The case of whitewater kayakers'. Journal of Park and Recreation Administration, 11(1): 67-77.

Shirky, C. (2009). 'How cellphones, Twitter, Facebook can make history'. In E. Frawley Bagley, ed.TED@State. Washington, DC, USA: TED Talks.

Southeastern. (2011). 'Greenwich'. nationalrail.co.uk. Available at: http://www.nationalrail.co.uk/stations/gnw/details.html [Accessed August 11, 2011].

Starck, P. (2012). 'Philippe Starck + Quotes'. Starck.com. Available at: http://www.starck.com/en/philippe_starck/quotes/ [Accessed October 29, 2012].

Stickdorn, M. (2010a). 'Definitions: Service Design as an Interdisciplinary Approach'. In M. Stickdorn \& J. Schneider, eds. This is Service Design Thinking. Amsterdam, NL: BIS Publishing, pp. 28-34.

Stickdorn, M. (2010b). 'It Is An Itterative Process'. In M. Stickdorn \& J. Schneider, eds. This is Service Design Thinking. Amsterdam, NL: BIS Publishing, pp. 122-135.

Stickdorn, M. and Schneider, J. (2010). This is Service Design Thinking M. Stickdorn \& J. Schneider, eds.,. Amsterdam, NL: BIS Publishing.

Tapscott, D. and Williams, A.D. (2008). Wikinomics: How Mass Collaboration Changes Everything,. UK: Atlantic Books.

TFL. (2010). 'Step-Free Tube Guide'. tfl.gov.uk, London Und. Available at: http://www.tfl.gov.uk/assets/downloads/step-free-tube-guide-map.pdf.

Turner, A.J. (2006). Introduction to Neogeography,. [eBook]: O'Reilly.

Verhoef, M., Lurvink, M., Barf, H.A., Post, M.W.M., Van Asbeck, F.W.A., Gooskens, R. and Prevo, A.J.H. (2005). 'High prevalence of incontinence among young adults with spina bifida: description, prediction and problem perception'. Spinal Cord, 43: 331-340. 
WheelMap. (2012). 'Wheelmap - find wheelchair accessible places'. wheelmap.org. Available at: http://wheelmap.org/en/?a=b\&lat=50.2696687\&lon=-

4.7872174\&q=mevagissey\&zoom=17 [Accessed October 29, 2012].

Wood, D. (2003). 'Cartography is dead (thank god!)'. Cartographic Perspectives, 45(Spring): 4-7.

Woodcock, A. (2003). 'New insights, new challenges; person centred transport design'. Work, 41: 4879-4886.

Zielstra, D. and Zipf, A. (2010). 'A Comparative Study of Proprietary Geodata and Volunteered Geographic Information for Germany'. In M. Painho, M. Y. Santos, \& H. Pundt, eds. Geospatial Thinking: Proceedings of the 13th AGILE International Conference on Geographic Information Science. Guimarães, Portugal: AGILE, p. 1.

Zook, M.A., Graham, M., Shelton, T. and Gorman, S. (2010). 'Volunteered Geographic Information and Crowdsourcing Disaster Relief: A Case Study of the Haitian Earthquake'. World Medical \& Health Policy, 2(2): 7-33.

\section{BIOGRAPHY}

Christopher J. Parker is a Research Associate at Loughborough University Design School, focusing on the Usability of Volunteered Geographic Information from a Human Factors perspective. Andrew May and Val Mitchell are Research Fellows specialising in UserCentred Design of new technologies. Alison Burrows is a PhD student working alongside Parker, May and Mitchell, specialising in inclusive service design for older people.

\section{ACKNOWLEDGEMENTS}

This study was undertaken within the Ideas in Transit project (www.ideasintransit.org), funded by the UK government (via the Engineering and Physical Sciences Research Council, the Technology Strategy Board and the Department for Transport). Thanks also to mySociety.org for providing the data for case Study 2. 